\title{
MEDYA SEKTÖRÜNDE ÇALIŞAN KADINLARIN KONUMU VE YAŞADIKLARI ZORLUKLAR: ORDU YEREL MEDYASINDA ÇALIŞAN KADINLAR VE ULUSAL GAZETE KÜNYELERININ İNCELENMESI
}

\author{
POSITION AND DIFICULTIES OF WOMEN WORKING IN THE MEDIA \\ SECTOR: WOMEN WORKING IN ORDU LOCAL MEDIA AND ANALYSIS \\ OF NATIONAL NEWSPAPER MASTHEADS
}

\author{
Merve SARIŞIN1
}

\begin{abstract}
ÖZ
Var olduğu her dönemde ataerkil yapının ikincisi konumunda olan kadın, toplumsal cinsiyet ile ilgili rol ayrımları nedeniyle uzun süre anne ve eş kimliği ile özel alana hapsolmuştur. Tarihin ilk dönemlerinden bu yana üretime aktif olarak katılan ancak emeği görmezden gelinen kadın, Sanayi Devrimi ile birlikte çalışma hayatında görünür olmaya başlamıştır. Fakat bu durum onların erkekler ile eşit statüde çalışmasının ve eşit ücret almasının önünü açmamış ayrıca bulundukları pozisyonun üstüne çıkmalarına ya da farklı departmanlarda çalışmalarına engel olmuştur. Cam tavan ve cam duvar sendromu olarak adlandırılan bu durum çoğu sektörde olduğu gibi medya sektöründe de halen varlığını sürdürmektedir. Bu çalışma da medyada çalışan kadınların toplumsal cinsiyet ekseninde dikey ve yatay ayrışmaya ne oranda maruz kaldıklarını ve iş hayatında karşılaştıkları sorunları açıklamaya çalışmaktadır. Bu bağlamda ulusal yayın yapan gazete künyeleri incelenmiş ayrıca Ordu yerel medyasında çalışan kadınlar ile derinlemesine görüşme yapılmıştır.
\end{abstract}

Anahtar Kelimeler: Toplumsal cinsiyet, medyada çalışan kadınlar, cam tavan sendromu

\begin{abstract}
The woman, who was the second of the patriarchal structure in every epoch of her existence, was imprisoned to the private area with mother and spouse identity for a long time due to her gender-related role differences. The woman, who has been actively participating to production since the early epoch of history, but ignored labor, has become visible in the business life with the Industrial Revolution. But, this situation did not pave the way for them from working with men in equal status and getting equal wages, and also prevented from exceeding their positions or working in different departments. This status, which is called glass ceiling and glass wall syndrome, still exists in the media sector as in most sectors. This study tries to explain the extent to which women working in the media are exposed to vertical and horizontal separation around gender and the problems they face in business life. In this context, national broadcast mastheads were examined also in-depth interviews were made with women working in the local media of Ordu.
\end{abstract}

Keywords: Gender, women working in the media, glass ceiling syndrome

1 Öğretim Görevlisi, Ordu Üniversitesi, Ulubey Meslek Yüksekokulu, Gazetecilik ve Habercilik Bölümü, Giresun Üniversitesi Sosyal Bilimler Enstitüsü İletişim Bilimleri Anabilim Dalı Doktora Öğrencisi, mervesarisin@odu.edu.tr, orcid.org/0000-0002-1144-1843

Sorumlu yazar / Corresponding Author: Merve SARIŞIN, e-posta: mervesarisin@ odu.edu.tr 


\section{GíRİş}

Bedenlerimize bağlı kadın ya da erkek olmanın bize kazandırdığı cinsiyet kimliğinin yanı sıra günümüzde cinsiyet kavramından farklı bir anlamla adı anılan toplumsal cinsiyet kavramı; içinde bulunduğumuz toplumun sosyal kültürel özelliklerinin, değer ve normlarının, bir duruma karşı kadın ya da erkek olarak -bize atfedilen toplumsal rollerle- nasıl davranmamız gerektiğinin öğretildiği bir kavram olarak karşımıza çıkmaktadır.

Toplumsallaşma süreci içerisinde ilkel dönemlerden günümüze dek üretim faaliyetleri içerisinde yer alan kadınlar, üretim alanında her dönemde erkeklerle aynı, hatta çoğu zaman onlardan daha fazla rol üstlenmişlerdir. Fakat patriyarkal düzen içerisinde üretime katkısı büyük oranda görmezden gelinen kadın; çocuk doğurma, yaşlı bakımı ve karşılıksız olarak ev işlerini yapma gibi roller ile konumlandırılmıştır. $\mathrm{Bu}$ da kadınların ev içerisinde yani özel alanda, erkeklerin ise çalışma hayatında -kamusal alanda- var olması düşüncesine temel oluşturmuştur. Kadınlara yüklenen bu rol ve sorumluluklar onları her defasinda kamusal alana "anne ve eş" kimliğiyle katılmaya zorlamış; kadının yerinin evi olduğuna ilişkin güçlü toplumsal yarg1, onların iş yerlerinden dışlanmalarını, emek piyasasında belirli mesleklere yoğunlaşmalarını, hiyerarşik olarak erkeklerden daha düşük kademede çalışmalarını meşrulaştıran önemli bir referans düşünce olmuştur (Urhan, 2016, s. 123).

Her dönemde ev içinde ve dışında üretime katkı sağlayan fakat emeğinin karşıllı̆ını alamayan diğer bir deyişle ücretsiz aile işçisi olarak çalışan kadın 18. yüzyılda İngiltere'de başlayan Sanayi Devrimi’yle birlikte çalışma hayatında aktif olarak yer almaya başlamıştır. II. Dünya Savaşı sonrasında kadın iş gücü ekonominin birçok alanında kendini göstermiştir. Fakat bu durum kadının erkeklerle eşit statüde çalışmasını ya da onlarla aynı ücreti almasının önünü açmamıştır.

Pek çok alanda olduğu gibi medya sektöründe de birçok sorunla karşılaşan kadınların günümüzde de benzer sorunları devam etmektedir. Medya işletmelerinde çalışan kadınların konumunu ve yaşamış oldukları sorunların incelendiği bu çalışmada; toplumsal cinsiyet kavramı, bu alandaki çalışmaların ne zaman başladığına yönelik kısa bir tarihçe, medya endüstrilerinde çalışan kadınlar ve bu kadınların yönetim kademesindeki konumu bağlamında Türkiye'deki ulusal gazetelerin künyeleri incelenmiş ve Ordu ilindeki medya sektöründe çalışan kadınlar ile derinlemesine görüşmeler yapılmıştır.

\section{KAVRAMSAL ÇERÇEVE}

\subsection{Toplumsal Cinsiyet Tanımı ve Tarihi Ardalanı}

Cinsiyet terimi anatomik ve fizyolojik farklılıkları dile getirmek için, bedenin dişi ve erkek olarak tanımlanmasıyken söz konusu cinsler arasındaki toplumsal farkl1liklarla yönelik olarak da toplumsal cinsiyet terimi kullanılmaktadır. $\mathrm{Bu}$ bağlamda toplumsal cinsiyet, toplumsal olarak kurulan erillik ve dişillik kavramlarıyla ilişkilidir, bireyin biyolojik cinsiyetinin doğrudan bir sonucu olmak zorunda değildir (Giddens, 2012, s. 478).

Toplumsal cinsiyet kavramını eşit olmayan bir 
toplumsal düzen olarak tanımlayan ayrıca kültürel olarak kadını ve erkeği toplumsal bir kadına ve erkeğe dönüştüren kategori olarak açılayan (Savran'dan aktaran Sayg1ligil, 2016, s. 10-11) “Hem ayrımcı, eşitsiz, baskıya dayalı bir toplumsal düzenin adıdır toplumsal cinsiyet hem bu ilişkinin taraflarını oluşturan toplumsal grupları dile getiren bir kategori: ama hem de bu grupların mensuplarının psikolojik ve davranışsal özelliklerine göndermede bulunur.” der.

Kadınlar ile erkekler arasındaki farklılıkların toplumsal düzlemde kurulmuş yönlerine dikkat çeken Marshall (1998, s. 98), toplumsal cinsiyet kapsamının -ilk ortaya çıkışından beri- yalnızca bireysel kimliği ve kişiliği değil, ayrıca sembolik düzeyde erkekliğin ve kadınlığın kültürel idealleri ile stereotiplerini, yapısal düzeyde ise kurumlar ve örgütlerdeki cinsel iş bölümünü içine alacak kadar genişlediğini belirtir.

İkinci dalga feminist hareketin önde gelen isimlerinden olan ve feminist kuramın çıkışında rol oynayan Simone de Beauvoir (1993, s. 231) yazdığ "İkinci Cins" adlı kitabında "İnsan kadın doğmaz: sonradan olur. İnsan dişisinin toplum içerisindeki görünüşünü belirleyen biyolojik, ruhsal ve iktisadi bir yazgı yoktur" diyerek kadın ve erkek arasındaki farkın toplum içerisinde onlara yüklenen rollerle, toplumsal etkilerle anlam kazandığını ifade etmiş ve toplumsal cinsiyete vurgu yapmıştır.

Sosyal bilimler alanında ilk olarak feminist çalışmalar sonra kadın çalışmaları olarak adlandırılan, son zamanlarda ise ad1 toplumsal cinsiyet çalışmaları olarak anılan bu çalışma alanı 18. yüzyılın sonları ile 19. yüzyılın başlarında filizlenmiş̧tir. Feminizm tarihinde üç kuşak olarak karşımıza çıkan kadın hareketlerinin ilk dalgasına yani 20. yüzyılın ilk yarısına kadar olan sürece kadınların oy hakkı mücadelesi damga vurmuşstur. Mary Wollstonecraft'in 1792 yilında yayımlanan "Kadın Haklarının Gerekçelendirilmesi” adlı kitabı ise ilk feminist metinlerdendir. Wollstonecraft, kadınların özerk bireylere dönüşmeleri için karşılarındaki toplumsal, kültürel ve eğitimsel engellerin kaldırılması gerektiğini savunarak kadınların bağımlılığının toplumdan kaynaklandığını savunmuştur. Wollstonecraf, "Kadın Haklarının Gerekçelendirilmesi” yapıtında cinsiyet eşitliğinin bir insan hakkı olduğunu savunarak kadınların aşağ 1 konumunun daha az akıllı olmalarından değil toplumsal olarak erkeklere bağımlı olmalarından kaynaklandığını belirtmiş, kadınların akıl sahibi bilinçli varlıklar olduğunu ve erkeklerle eşit haklara sahip olması gerektiğini söyleyerek eşitliğin sağlanması için toplumsal bir değişime gerek duyulduğuna vurgu yapmıştır (Berktay, 2013, s. 4).

Feminizmin ikinci dalgası olarak nitelendirilen süreçte ise iş bölümü, cinsellik, beden, toplumsal cinsiyet rolleri ve kadının ezilmişliği kavramları üzerinde durulmuştur. Kadın pratikleri, kimlik, inşa ve temsil gibi konuların tartışıldığı bu dönemde ayrıca özel alan-kamusal alan ayrımına da dikkat çekilmiştir. Feminist felsefenin önde gelen isimlerinden olan Simone de Beauvoir 1949'da yayımladığı "İkinci Cins (The Second Sex)" adlı kitabı ile sadece kadın erkek ilişkilerine değil aynı zamanda birçok eşitsiz ezme ve ezilme ilişkilerinde var olan "öteki” kavramını da dolaşıma sokmuştur. Aynı zamanda erkeğin ötekisi olarak nitelendirilen kadının kamusal alanda özellikle iş ve eğitim alanında bedensel ve ev içi işlerde kendisine 
atfedilmiş rolleri aşarak gerçekleştirmesini bir proje olarak önemsemiştir (Yazıc1, 2016, s. 69-72).

Yine ikinci dalga döneminde kadınlar kişisel deneyimlerini paylaşarak aralarındaki benzer sorunları ortaya koymak için "kız kardeşlik” kavramı etrafında toplanarak "bilinç yükseltme grupları oluşturmuşlardır. Bu gruplarda evlilik, annelik, cinsellik gibi pek çok konuda kişisel deneyimler paylaşılarak kadınların ortak bir eril baskı altında olduğu vurgusu yapılmıştır (Berktay, 2013, s. 6).

Post-modern dönemde beliren Üçüncü Dalga Feminizmi, ikinci dalga feminizminin kadınların ortak deneyimlerine odaklanmasına ve farklılıkları göz ardı etmesine eleştiri getirerek kadınlar arasındaki farklılıkların dile getirilmesi gerekliliğine vurgu yapmıştır. Kadın olmak hem bir cinsiyet rolü hem de bir kimlik olarak tanımlanmaktadır. Kadın kimliği, erkek kimliğinden farklı olarak iktidar kavramından uzaktadır. Erkek kimliği, farklılıkların üzerinde baskı kurma eğilimi barındırırken, kadın kimliği bundan uzaktır. Dolayısıyla da farklılıklar, kadın kimliği içerisinde rahatlıkla barındırılabilmektedir. Üçüncü Feminist Dalga, bu farklılıkların dile getirilmesine ve yaşatılmasına vurgu yapmıştır (İlker'den aktaran Kılıç: 2013, s. 26). Üçüncü Dalga hareketin önemli düşünürlerinden olan Luce Irigiray, kadının bir cinsiyet olarak bile görülmediğini, sadece erkek cinsiyetinin öne çıktığı bir dünyada kadının da cinsiyetinin var olduğunu göstermesinin de feminist bir mücadele olduğu kadar kadının kendindeki indirgenemez çoğulluğu görmenin bir yolu olduğunu belirtmiştir (Yazıcı: 2016, s. 74).

Post-modern feminist yaklaşım da kadınlar arasındaki farklılıklara karşı duyarlı olmasına karşın söz konusu farklılıkları sadece söyleme indirgediği için kadınların mücadelesini sekteye uğrattığ gerekçesiyle eleştirilmiştir.

\subsection{Kadının İstidam Süreci, Medya Endüstrisinde Çalışan Kadınlar ve Karşılaştıkları Zorluklar}

İlkel dönemlerden günümüze dek üretim faaliyetleri içerisinde yer alan kadınlar üretim alanında her dönemde erkeklerle aynı, hatta çoğu zaman onlardan daha fazla rol üstlenmişlerdir. Her dönemde ev içinde ve dışında üretime katkı sağlayan fakat emeğinin karşılığını alamayan kadınının Sanayi Devrimi'yle birlikte kamusal alana katılımı artmış ve kadın, emeği karşılığında ücret almış ayrıca bu dönemle birlikte kadın hakları da gündeme gelmeye başlamıştır.

Birinci ve İkinci Dünya Savaşlarının olduğu dönemde erkeklerin orduya katılması ve onlardan boşalan iş gücü açığını kadınların doldurması, kadınların kendi statülerinin farkına varmasını ve eğitim durumlarının da yükselmesini beraberinde getirmiştir. Yine bu dönemde kadınlar Avrupa'da örgütlenerek eşit işe eşit ücret talepleriyle de kamusal alanda seslerini duyurmaya başlamışlardır. Sonuç itibariyle kadınlar -başlangıç noktası Sanayi Devrimi olarak kabul edilen- çalışma hayatında hem aktif olarak yer almış hem de yönetim ve idari süreçlerde de söz sahibi olmuştur (Korkmaz, 2015, s. 242-244).

Türkiye'de de 20. yüzyılın başlarında yaşanan savaşlar nedeniyle erkeklerin silah altına alınması, kadınların kamusal hayata dahil olmaya başlamasının nedenleri arasında yer alabilir. Bununla 
birlikte 1923 y1lında Cumhuriyet'in kurulması ile kadınlara ücretsiz eğitim zorunluluğu getirilmiş ve pek çok alanda hak elde eden kadının kamusal alanda görünürlüğü de artmıştır. 1926 yılında Medeni Kanun'un kabulü ile kadınların eşit haklara sahip olmasının önündeki engeller kısmen kaldırılmış, bununla birlikte kanunda kadının çalışması için kocasından izin alması gerekli görülmüştür. Takip eden 1930 ile 1934 yılları arasında kadına seçme ve seçilme hakkı verilmiş, 1936 yılında kabul edilen İş Kanunu ile kadınların çalışma hayatına katılımı sağlanmıştır. Getirilen bu haklarla birçok kadın eğitim, siyasal katılım ve istihdam firsatı elde etmiştir (Madeline'den aktaran Alpsoy, 2016, s. 8).

Tüm bu tarihsel gelişmelerle birlikte kadınlar her ne kadar belirli dönemlerden sonra kamusal hayatta görünür olup iş gücüne katılım sağlamışlarsa da bu durum onların çalıştıkları yerlerde erkeklerle aynı konumda olmalarına ya da daha üst kademelerde yer almalarına olanak tanımamıştır.

Türkiye'de 1990'ların başından itibaren özel yayın yapan kuruluşların sayılarının giderek artmasiyla medyada ve sinemada kadınların sayıları artmış ve görece daha üst konumlara gelebildikleri gözlenmiş olsa da medyada çalışan kadınlar genelde orta düzeydeki pozisyonlarda, erkekler ise yönetim kademesinde yer almıştır (KSGM, 2008, s. 11). Bu durumda medyada orta düzeyli yöneticilikten üst kademeye çıamayan kadınlar genellikle yayın bölümlerinde yer almış, magazin sayfası, editörlük, yazı işleri alanlarında çalışmışlardır.

Medyada çalışan kadınların yaşadığı sorunları ağır çalışma koşulları, toplumsal ayrımcılık, mobbing, iş güvencesizliği, sosyal güvenlik, ücret ve cam tavan sorunu olarak belirten Kuyucu (2013, s. 41-43), diğer sektörlerde olduğu gibi medyada çalışan kadınların da karşılaştığ önemli sorunlardan birinin toplumsal cinsiyetçi tutumlar olduğunu ifade ederek Batılı ülkelerde yapılan çalışmalarda da kadın iş gücünün dağılımı açısından basında yatay ve dikey olmak üzere iki farklı ayrımcılık gözlendiği tespit edildiğini ifade eder. Bununla birlikte yatay ayrımcılı̆̆ın, diğer deyişle cam duvarların, basın sektöründe çalışan kadınların belli sayfalarda istihdam edilmesine ilişkin olduğunu ifade ederek kadın gazetecilerin magazin departmanında daha çok istihdam edilirken spor alanında sayılarının yok denecek kadar az olduğuna vurgu yapar.

Dikey ayrışma ise kadın ve erkeklerin birlikte çalıştıkları iş yerlerinde kadınların üst düzey konumuna gelememelerini ifade eder. Cam tavan olarak da adlandırılan dikey ayrışma, yasal olmadığ halde varlığ 1 gözle görülmeyen bariyerleri belirtmek için kullanılır (Urhan, 2016, s. 142). TÜİK 2017 verilerine göre Türkiye'deki üst ve orta kademe yönetici konumunda çalışan kadın oranının yüzde 17,3 olması dikey ayrımcılığa örnek teşkil eden bir durumdur.

\section{ARAŞTIRMANIN YÖNTEMI VE BULGULAR}

\subsection{Araştırmanın Yöntemi}

Gerçekleştirilen bu çalışmada daha önce Çiçek Tahaoğlu'nun 2014 yılında ulusal gazetelerde çalışan kadın ve erkek oranları üzerine yapmış olduğu araştırmanın güncellenmesi ile Ordu yerel medyasında (gazete, televizyon) çalışan kadınların konumlarının bulguları yer almaktadır. Gerek ulusal 
gerekse yerel medyada çalışan kadınların üst ve orta düzeydeki konumlarının ne olduğu ve söz konusu konumlarının cam tavan ve cam duvar sorunlarını ne ölçüde yansıttığının araştırılmasının amaçlandığg bu çalışmada saha araştırması temelinde derinlemesine görüşme yöntemi kullanılarak kadın katılımcıların çalışma şartları, çalıştıkları pozisyonlar ve yaşadıkları sorunlar Ordu yerel medyasında çalışan kadınlar ölçeğinde incelemeye alınmıştır.

\subsection{Bulgular}

\subsubsection{Ulusal Gazete Künyelerinde Yer Alan} Kadın ve Erkek Oranları

$\mathrm{Bu}$ araştırmada Tahaoğlu'nun "Medyanın Künyesi: Kaç Kadın Kaç Erkek?” isimli çalışması baz alınarak araştırma güncellenmeye çalışılmıştır. 2014 y1lından sonra gerek "15 Temmuz Darbe Girişimi” gerekse çeşitli nedenlerden dolayı kapatılan gazeteler dışarıda bırakılarak bir araştırma yapılmıştır. 2014 yılında yapılan bu çalışmada 30 ulusal gazete künyesi incelenerek çalışanların yüzde 19'unun kadın yüzde 81'inin erkek olduğu sonucuna ulaşılmıştır. Söz konusu araştırma sonuçlarına göre yazılı basın yöneticilerinin yüzde 10'u kadın yüzde 90'1 ise erkektir.

2014'te yapılan araştırmanın güncel hale getirildiği bu çalışmada kapatılan ve tematik basın alanına giren gazeteler (spor, ekonomi vb.) dışarda bırakılmış ve 21 günlük gazete incelemeye dahil edilmiştir. İncelemeye alınan gazeteler Akit, Akşam, Aydınlık, Cumhuriyet, Evrensel, Güneş, Habertürk, Hürriyet, Milat, Milliyet, Milli Gazete, Orta Doğu, Posta, Sabah, Sözcü, Star, Takvim, Türkiye, Vatan, Yeni Şafak ve Yurt gazeteleridir. Yapılan incelemeler sonucunda gazete künyelerinde yer alan çalışanların yüzde 14'ünün kadın yüzde 86'sının ise erkek olduğu sonucuna ulaşılmıştır. Bununla birlikte yazılı basın yöneticilerinin yüzde 5'i kadın, yüzde 95'i erkektir. Aynı zamanda gazetelerin spor ve ekonomi editörlügünde kadın çalışana rastlanmamıştır. Sonuçlardan da anlaşılacağı üzere incelemeye alınan gazetelerde yatay (cam duvar) ve dikey (cam tavan) ayrışmaların varlığı belirgin bir şekilde göze çarpmaktadır. Yazılı basının sadece yüzde 5'lik kısmında kadın yöneticilerin yer alması dikey ayrışmanın varlığına örnek oluştururken incelenen gazeteler arasinda kadın spor ve ekonomi editörlerinin olmaması da yatay ayrışmanın varlığına örnek teşkil etmektedir.

"Medyanın Künyesi: Kaç Kadın Kaç Erkek?" çalışmasının 2014 y1lı verilerine göre medyada çalışan kadın oranın yüzde 19, yazılı basın yöneticilerinin yüzde 10’u kadındır. Bu araştırmayı güncel hale getirdiğimiz çalışmamızda ise medyada çalışan kadın oranı yüzde 14, basın yöneticilerinin ise yüzde 5'inin kadın olduğu sonucuna ulaşılmıştır. 2014 yılından bugüne medyada çalışan kadınların oranındaki azalışın sebeplerinden bir tanesi kapatılan ve tematik alandaki gazetelerin incelemeye alınmaması olarak açıklanabileceği gibi söz konusu oranlar 6 yıl içerisinde ataerkil cinsiyetçi yapının herhangi bir değişime uğramaması olarak da okunabilir.

\subsubsection{Yerel Medyada Çalışan Kadınların Konumları: Ordu Örneği}

Araştırmamızın bu kısmında Ordu'da gazete ve televizyonlarda çalışan kadınlar ile derinlemesine görüşme yapılmıştır. Ordu'da toplamda 10 gazete, 4 
televizyon (ulusal yayın yapan 2), 7 radyo bulunmaktadır. Araştırmaya dahil edilen gazeteler tirajlarına göre, kanallar ise ulusal yayın yapma özelliklerine göre değerlendirilmiştir. Ordu'da bulunan radyoların araştırma dışında bırakılma sebebi ise radyo çalışanlarının tamamının erkeklerden oluşmasıdır.

Görüşmeler Ordu Olay, Tribün, Yeni Dönem, Hürses Gazetelerinde çalışan kadınlar ile TV 52 ve Altaş TV'de çalışan kadınlarla gerçekleştirilmiştir. Medyada çalışan kadınların nitelikleri, konumları ve yaşadıkları cinsiyetçi tutumları ortaya çıkarmayı amaçlayan bu çalışmada kadınlara aşağıdaki sorular sorulmuştur:

- Genel hayat hikayenizden bahseder misiniz?

- Ne zamandan beridir burada çalışıyorsunuz? Daha önce nerede çalıştınız?

- Kurumunuzda kaç kişi çalışıyor ve kaç tanesi kadın? $\mathrm{Bu}$ kişilerin eğitimleri nedir, üniversite mezunu mu?

- Kurumunuzun sahibi kimdir? Çalışanların bu kişiyle akrabalıkları var mıdır?

- Çalışma tarzınızı anlatır mısınız? Normal bir gününüz nasıl geçiyor?

- $\quad$ İş yerinizde kaç kadın kaç erkek çalışmakta. Konumları farklı mı, neden?

- İşe başladığınızdan bu yana görev veya sorumluluklarınızda bir değişiklik oldu mu (unvan vb.) ne zaman, nasıl, neden?

- Kurumunuzda kadın ve erkeğe karşı olan davranışlarda bir değişiklik var mı?

- $\quad$ İş yerinizde işinizi yaparken kadınlara karşı kullanılan cinsiyetçi ifadelerle karşıllaşıyor musunuz? Bu duruma karşı nasıl bir tepkiniz oluyor?

- $\quad$ Sizce genelde medya sektöründe kadınlara karşı ayrımcılık yapılıyor mu? Hangi alanlarda, nasil?

\subsubsection{Görüşme Yapılan Kadınların Demografik Özellikleri}

Görüşme yapılan kadınların demografik özelliklerine baktığımız zaman kadın çalışanların hepsinin Ordulu olup 4'ü evli 2'si bekardır. Farklı yaş grubuna ait olan kadınların yaş ortalaması 33 iken eğitim düzeyleri 4'ü üniversite 2'si lise mezunu şeklindedir. Üniversite mezunu olanların içerisinde 3 kadın iletişim fakültesinden mezun olmuştur.

\subsubsection{Araştırmaya Dahil Olan Yayın Organlarındaki Kadın-Erkek Çalışanların Sayısı}

İncelenen yayın organları arasında yer alan Tribün Gazetesi dışındaki tüm mecralarda kadın çalışanların sayısı erkek çalışanların sayısından azdır. Şöyle ki, Ordu Olay gazetesinde 8 kişiden 2'si, Yeni Dönem gazetesinde çalışan 8 kişiden 3'ü, Hürses gazetesinde çalışan 7 kişiden 3'ü kadındır. Bununla birlikte 1983 yılından beri varlığını sürdüren Tribün gazetesinde ise genelin aksine kadın çalışanların sayısı 7 iken erkek çalışan sayısı 2 olduğu görülmüştür. Ayrıca Yeni Dönem gazetesinin spor departmanında sadece kadın muhabirin çalışması da söz konusu gazetede yatay ayrışmanın olmadığını göstermektedir. Genel itibariyle 
incelemeye aldığımız yerel gazetelerdeki erkek çalışan sayısının kadınlara göre fazla olmasını, ulusal gazetelerde karşımıza çıkan aynı tablonun yerel medyaya yansıması olarak da anlamlandırabiliriz.

\subsubsection{Medya Sektöründeki Kadınların Çalışma Hayatları ile İlgili Sorunlar}

Hem özel sektör olmasından dolayı hem de uzun ve yoğun çalışma saatleri gerektiren medya sektörünün özellikle kadınlar için birçok zorluğu olduğu söylenebilir. $\mathrm{Bu}$ bağlamda kadınlara yöneltilen "Çalışma tarzınızı anlatır mısınız? Normal bir gününüz nasıl geçiyor?” soruları sorularak ev ile iş arasında denge kurmada bir zorluk yaşayıp yaşamadıkları öğrenilmeye çalışılmıştır. Verilen cevaplar şu şekildedir:

Gazete (K. G. 1): Aktif olarak çalıştı̆̆ım dönemlerde aşırı derecede yorucuydu, sabah başlayıp Ordu'daki bütün resmi kurumları birer birer ziyaret edip haber topluyordum, öğlene doğru gazeteye gelip haberleri yazlyordum. Hiçbir zaman mesai saatine bă̆ll olarak çalışmadım, işim ne zaman bittiyse eve o zaman gittim. Çocuklarımın ikisi de üniversiteden mezun oldular, büyüdükleri için beni şu an yoran çok fazla bir şey yok. Onlar doğduklarında ise kayınvalidemle birlikte oturuyordum, çocuklarıma evde kayınvalidem baktı o yüzden şanslı olduğumu düşünüyorum.

Habercilikte önceki günden kalan hiçbir şey olmuyor, akşam her şeyi çöpe atıp ertesi gün yeni baştan başlıyorsunuz. Her gece yattı̆̆ımda yarın ne haber yapacă̆ım?' diye uyku uyuyamazdım. Haber stresi yaşamak kadar kötü bir şey yok. Son 6-7 yıldır rahatım, haber işine çok fazla girmek istemiyorum.
Gazete (K. G. 2): Çalışma saatimiz sabah 9 akşam 6 şeklinde. Dışarıda çalışan tek ben varım. Haberlere gidiyorum, özel haber ve haftada bir kere röportaj yapma zorunluluğum var. Bazen çok yoğun oluyorum tek başıma yetişemiyorum bazen de akşama kadar oturduğum zamanlar olabiliyor. Henüz evli olmadığımdan dolayı ev ile iş arasındaki dengede bir problem olmuyor, annem de çalıştığ için aynı saatlerde eve gelip birlikte mutfăga giriyoruz.

Gazete (K. G. 3): Mesaim sabah 8'de başliyor. Muhabir olduğum için genelde dışarda oluyorum varsa programlara gidiyorum olmazsa özel haber yapıyorum, iş yerine gelip hem ajanstan düşen haberleri hem de kendi yaptı̆̆ım haberleri yazıyorum. Akam çıkış saatim 18.30 fakat akşam haber yapılmasi gerekiyorsa eve 10.00'da gittiğim de oluyor. Bekar olduğum için ev ile iş arasında denge kurmada bir problem yaşamıyorum.

Gazete (K. G. 4): Bizim mesaimiz sabah 09.00 gibi başlar. Çalışan arkadaşlarla iş bölümü yaparız. Herkes toplantısına, haberine gider ve akşam 16.00 gibi haberler bir havuzda hazırlanır. Ardından sayfalara dağıtımı yapılır. Akşam en geç 18.30'da da işimiz sona erer.

Televizyon (K. G. 5): Sabah programı yaptı̆̆ım için 7.30'da burada oluyorum. Akşam çıkışımız ise 7'yi buluyor. Aslında yerel kanallar ne kadar yoğun olabilir gibi bir düşünce olabilir ama yerel kanallar daha çok yorulabiliyor, çünkü bir kişi birçok işi yapıyor. Örneğin haberin yapılması, seslendirilmesi ve montajı tek kişiye ait olabiliyor. Ulusal kanalda bir kişi günde iki haber peşinde koştururken burada kişi başına 3-5 haber düşebiliyor. Daha gün ışımadan başladığımız iş̧imizi zifiri karanlıkta 
bırakıp eve gidiyoruz. Evliyseniz ve haftada bir gün izniniz varsa bunu ya temizliğinize ya da ütünüze ayırabiliyorsunuz. Kendinize ait hiçbir vakit diliminiz yok. Yemeğinizi ya yapabiliyorsunuz ya da hazır gldalar tüketmek zorunda kalyyorsunuz, sağllklı ya da güzel bir ev hayatınız olmuyor. Bu da zaman zaman tartışmalara ve isyana da yol açabiliyor. Bu da ya mesleğimi bıraksam ya da keşke evlenmese miydim dedirtebiliyor.

Televizyon (K.G.6): Sabah 7 buçuk gibi evden ayrllip kanalda oluyorum hizlıca bir hazırliktan sonra canl yayına giriyorum. Hafta içi her gün 2 buçuk saat süren uzun bir programım var. Canlı yayının ardından haber merkezindeki görevim devam ediyor. Mesai sonunda ise eve gidip evdeki işlerle ilgileniyorum. Haftada bir olmak üzere akşam yayınım da bulunuyor. Akşam programımın olduğu salı günleri eve daha az vakit ayırabiliyorum. Haftalık programa bakıldı̆̆ında iş anlamında oldukça hareketli geçiyor.

Alınan cevaplara göre kadınların çalışma hayatlarının yoğun ve yorucu olduğu bekar kadınların ev ile iş arasında denge kurmada herhangi bir sorunla karşılaşmadıkları, evli olanların ise iş temposundan dolayı zorlandıkları, bu durumun zaman zaman tartışmalara da yol açtığ görülmektedir.

\subsubsection{Yayın Organlarında Çalışan Kadınların Konumları}

Görüşme yapılan kadınların bulundukları konumlarıyla ilgili olarak "İ̧s yerinizde kaç kadın kaç erkek çalışmakta. Konumları farklı mı, neden?” sorusu ile kadınların iş hayatında çokça karşılaşmış oldukları yatay ve dikey ayrışma, yerel medya sektörü referans alınarak örneklendirilmeye çalış1lmıştır.

Gazete (K. G. 1): İş yerimizde 20 erkek 3 kadın çalışmakta. Ben burada sorumlu yazı işleri müdürüyüm, diğer kadın arkadaşımız sayfa sekreteri, bir kadın arkadaşımız da mutfakta çalışmakta. Haber müdürümüz, spor muhabiri ve diğer muhabirlerimiz erkek. Konum farklılı̆̆ının sebebini Ordu'da basınında yeni muhabir yetişmemesine bağllyorum.

Gazete (K. G. 2): 5 kadın 2 erkek çalı̧̧maktayız. İki kişi dizgi işi yapmakta biri aynı zamanda yazı işleri müdürlüğü de yapmakta. Haberleri ben hazırlıyorum. Grafiker arkadaşımız daha çok reklam, afiş, kartvizit işleri ile uğraşmakta. Yeni gelen arkadaşımız ise muhabirlik yapıyor ve şu an işi ögrrenme aşamasında. Konumlarımızın farklı olmasının nedeni diğer arkadaşlarımızın uzun yıllardır burada çalışıyor olması diyebilirim.

Gazete (K. G. 3): Toplamda 13 kişi çalışmaktayız. Çalışanlar hangi alanlarda yetkinse buna göre konum farklılı̆̆ı olabiliyor, aynı zamanda tecrübe de önemli. Ĕger biri yazı işleri müdürü olmuşsa nedeni o alanda tecrübeli olmasından dolayıdır.

Gazete (K. G. 4): Kurumumuzda 5 erkek ve 2 kadın çalışmaktayız. Yazı İşleri Müdürlüğünü ben yapmaktayım ve Sayfa Sekreterliği görevini de diğer kadın arkadaşım Dilek Tiryaki üstlenmektedir. Diğer çalışan erkek arkadaşlarımız ise muhabir olarak çalışmaktadırlar. Kadınlar iş yerindeki iç işlerini yönetirken, erkekler daha çok dışarı işine bakmaktadirlar. 


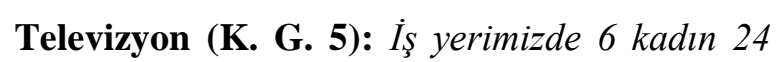
erkek çalışmakta. Yerel ölçekli kuruluşlarda erkek daha rahat her yere ulaşır düsüncesiyle belirli konumlarda erkek tercih edilebiliyor. Aslında bu mesleğin kirliliğinden de kaynaklanıyor olabilir. Toplumun genel kabulü erkek ă̆ırlıklı olduğundan da kaynaklanıyor olabilir.

Televizyon (K. G. 6): 30 personelin 8'i kadın 22 'si erkek. Görev tanımlamasi ihtiyaca ve başvurulara göre belirlenmekte, başka nedenlerden farklılık bulunmuyor.

Alınan cevaplara göre kadınların 3'ünün yazı işleri müdürü, 2'sinin muhabir, 1'inin ise program yapımcısı olduğu görülmektedir. Genel yayın yönetmenliği, yayın koordinatörlüğü gibi üst konumlarda erkeklerin olması, kadınların şu an bulunmuş oldukları en yüksek konumun yazı işleri müdürlüğü olması görünmeyen bariyerlerin bulunduğu cam tavan sendromunun varlığına işaret etmektedir. Spor departmanında çalışan hiçbir kadın muhabirin olmaması ya da ekonomi sayfasindan sorumlu bir kadın editörün bulunmaması yatay ayrımcılık da denilen cam duvarların kadınlar ile erkekleri konum olarak birbirinden ayırmaktadır.

\subsubsection{Kariyer ve Yükselme Olanakları}

Yönetim kademesinin büyük çoğunluğunu erkeklerin oluşturduğu bütün sektörler gibi medya sektörünün de yönetim kademesinde erkekler bulunurken kadınlar bulundukları konumdan üst konuma gelebilmek için erkeklerden daha fazla çaba sarf etmek zorunda kalmaktadır. Ordu yerel basınında da durum bundan farksızdır. Yazı işleri müdürlüğüne yükselen kadınlar daha önce muhabirlik görevinden bu konuma geldiklerini söylerken alınan cevaplar bu değişikliğin uzun bir süreç sonrasında gerçekleştiğini göstermektedir.

"İşe başladığınızdan bu yana görev veya sorumluluklarınızda bir değişiklik oldu mu (unvan vb.) ne zaman, nasıl, neden?" sorusuna verilen yanıtlar şöyledir:

Gazete (K. G. 1): İşe ilk olarak muhabiri olarak başladım, sonra haber müdürü oldum şu an ise sorumlu yazı işleri müdürüyüm. Çok uzun yıllar muhabir olarak çalıştıktan sonra bu konuma geldiğimi söyleyebilirim. Aslında Ordu'da basın sektöründe bunlara çok fazla takılmamak gerekir, çoğu zaman birbirimizin işini yapabiliyoruz.

Gazete (K. G. 2): Muhabir olarak başladım hala muhabirim zaten 1.5 yıldır çalışmaktayım.

Gazete (K. G. 3): Görevimde bir değişiklik olmadı zaten bu görev üstünüze yapışıp kalmakla beraber bunun üzerine farkl görevler de yüklenebiliyor. Örneğin gazetede muhabirken, aynı gazetenin televizyonunda program ya da radyo haberi de yapabiliyorsunuz. Yerel ölçekli gazete, radyo ve televizyonda birden fazla iş yapmanız mümkündür.

Gazete (K. G. 4): Olmadl. 2006 yllından beri bu gazetede Yazı Işleri Müdürlüğü görevini yapmaktayım.

Televizyon (K. G. 5): Evet oldu, fakat 10 yllın ardından oldu. Başlarken muhabir olarak başladım şu an haber merkezinde sorumlu müdür görevindeyim, bu sorumluluk maddi anlamda değil daha çok yönlendirme anlamında bir sorumluluk 
oldu benim için. Ayrıca meslekte kalifiye eleman sıkıntısı var. Bu işi istikrarla yapan kişi sayısı çok az o yüzden bu terfi biraz da kimsesizlikten kaynaklandl. Genelde yetki ve sorumluluk verileceği zaman akal bir erkeği ya da daha tecrübeli insanı arıyor ama bu sorumluluk bu konumda kimsenin olmamasindan dolayı geldi diyebilirim.

Televizyon (K. G. 6): İşe başladı̆̆ımdan bu yana reji montaj gibi birçok farklı departmanda çalıştım. Şu an aynı zamanda program yapımcisı olarak haber merkezinde çalışlyorum.

Alınan cevaplardan da anlaşılacağı üzere meslekte uzun yıllar çalışmış olan kadınların şu an bulundukları en üst konum yazı işleri müdürlüğü olmakla birlikte, bu konuma gelmeleri bir süreç gerektirmiştir. Bununla birlikte araştırmaya dahil olan kadın çalışanlar içerisinde mesleğe direkt olarak yazı işleri müdürlüğü ile başlayan olduğu gibi konumu ne kadar yükselirse yükselsin yerel medyada her zaman her işin yapıldığı görüşünde olan görüşmeci de vardır.

\subsubsection{7. İş Yerinde Karşılaşılan Cinsiyetçi}

\section{Söylemler, Cinsiyete Dayalı Tutum ve Davranışlar}

Kadınların çalıştıkları kurumda kadın ve erkeğe karş1 olan davranışlarda bir değişiklik olup olmadığına ve cinsiyetçi söylemlere maruz kalındığına dair sorulan sorulara karşı 5 kadın böyle bir durumla karşılaşmadıklarına dair cevap verirken 1 kadın, yöneticiler tarafından olmasa da iş arkadaşları tarafından zaman zaman karşılaştığını belirmiştir.

Televizyon (K. G. 5): Meslekte geçirdiğim 10 yıl içerisinde kurum yetkilileri tarafindan kadın çalışanlara karşı bir aşağllama, ötekileştirme ya da cinsiyetçi bir ifade ile karşılaşmadım. Ama erkek iş arkadaşlarımla tartıştığımda karşı taraftan 'sen sus, sen kadinsi ne anlarsin, sus ezerim seni' gibi ifadelere maruz kaldım. Bu duruma karşı tepkim çalışmaya ilk başladı̆̆ım dönemlerde tartışmayı ileriye götürmeyen bir şekilde çok çekingen ve korkaktı. Tecrübe edindikçe karşı tarafin bastırmaya çalışıyorsunuz ama yine de tartışmayı çirkinleşmemesi adına ileri taşımayan yine kadınlar oluyor.

\subsubsection{Genel Olarak Medyada Kadınlara Karşı Yapılan Ayrımcılık ile İlgili Düşünceler}

Gerek ulusal gerekse yerel medyada genel olarak kadınlara karşı herhangi bir ayrımcılık yapılıp yapılmadığına dair soruya 3 kadın evet cevabı verirken 3 kadın hayır cevabı vermiştir.

Gazete (K. G. 1): Gerek yerelde gerekse ulusal basında kadınlara karşı bir ayrımcılık yapıldığını düşünmüyorum.

Gazete (K. G. 2): Kadınlara karşı bir ayrımcılık yapıldığını düşünmüyorum.

Gazete (K. G. 3): Genel olarak baktı̆̆ımızda kadınlara karşı bir ayrımcılık olduğunu düşünüyorum. Örneğin, en iyi spikerler en iyi köşe yazarlarının çoğu erkektir. Bunun da yaşadığımız toplumun ataerkil bir toplum olmasindan, kadina daha az söz verilmesinden kaynaklandı̆̆ını söyleyebilirim.

Gazete (K. G. 4): Evet yapllyor. Burada kadınların erkeklerden bir adım önde olması 
istenmiyor. Yaptıkları beceriksiz ve güçsüz olarak gösterilmek isteniyor. 'Sen bunu yapamamıssin, ben daha iyi yaparım havasına giriliyor'. Tabii bu da çok güzel bir durum değil. Bir kadın gazeteci herhangi bir habere gitse ya da muhabirlik yapıyor olsa, erkekler ondan önce davranıp kişinin öne geçmesini önlemek istiyor. Fotoğraf alırken bile, itişip kakıştırllyyorlar. Bunlar istisnai olan tavırlar. Bazen de bizlere çok yardımcı olan beyefendiler de var tabii. Bu, zamanla toplumda yayginlaşacak ve her şey daha güzel olacak diye umuyorum.

Televizyon (K. G. 5): Ulusal ve yerel ölçekli düşündüğümüzde ister istemez bir ayrımcllı̆̆ın olduğunu düşünüyorum. Bu sektörde kadınsanız, hele de bakıml ve güzelseniz ama gayeniz gerçekten bu işi yapmaksa da bir yoklamadan geçiyorsunuz. İsinizden önce görüntünüz ön planda olabiliyor. Erkek sadece yaptı̆̆ı iş ile değerlendiriliyorsa kadın önce görüntü, karakter kriterinden geçiyor iş ise daha geri planda kallyor. Örneğin bir muhabir alınacaksa (bunu yaşadı̆̆ım için söylüyorum) erkeklerin CV'lerinin içeriğine kadınların CV'lerinin ise fotoğraflarına ve kadın olma özelliklerine göre değerlendirildiğini düşünüyorum. Erkekler tarafindan bizim hakimiyetimiz altında olsunlar ama çok da söz hakkl vermeyelim düşüncesinin olduğunu söyleyebilirim.

Televizyon (K. G. 6): Ayrımcılık yapıldı̆̆ııı düşünmüyorum. Bugün bakıp tartacak olursak birçok izleyicinin de takip ettiği çok başarılı kadınlar var. Bence bu kadınlar adına çok güzel bir durum. Önemli olan işini sevmek ve saygı duymak izleyicin takdiri zaten arkasindan geliyor.

Medya sektöründe kadın ve erkeğe karşı ayrımcılık yapıldığını düşünen kadınlar -her ne kadar kendi iş yerlerinde cinsiyetçi tutum ve davranışlarla karşılaşmadıklarını belirtseler dekadınlar işe alımlarda daha çok görselliğin ön planda olması, mesleklerini gerçekleştirirken erkekler tarafından geride bırakılmaları gibi birçok sorun ile karşılaştıklarını belirterek bu ve bunun gibi ayrımcılıkları patriyarkal düzenin getirmiş olduğu bir durum olarak düşünmektedirler.

\section{SONUÇ}

Yaşadıkları her dönemde üretimin mutfak kısmının görünmeyen emekçileri olan kadınlar Sanayi Devrimi ile birlikte kamusal alanda görünür olup emeklerinin karşılığını almış olsalar da günümüzde hala ataerkil düzenin devam ettiğini ve toplumsal cinsiyet eşitsizliğinin eğitim kurumları, iş yerleri, medya ve insanın toplumsallaşmasına katkıda bulunan birçok alanda yeniden üretildiğini ve yaygınlaştırıldığını söylemekle hata etmiş olmayız.

Özel yayıncılık şirketlerinin sayılarının 90'lardan itibaren hızla artmasıyla doğru orantılı olarak görsel medya ve sinemada kadınların sayısının arttığı, bununla birlikte daha üst konumlara gelebildikleri görülmektedir. Buna rağmen diğer sektörlerde olduğu gibi medya sektöründe de kadın çalışanların oranı erkek çalışanların oranından oldukça düşüktür. Ayrıca medya sektöründe çalışan kadınlar genelde orta düzeydeki pozisyonlardan üst konumlara geçememiş, buna bağlı olarak da yönetim kademesinin büyük çoğunluğunu erkekler oluşturmuştur.

Türkiye'de Tanzimat Dönemiyle birlikte kadının gazetecilik serüveni başlamış, 1950’li yıllarda 
gazetecilik okulları açılmasıyla kadınların basın sektöründe yer almaları kolaylaşmış olmasına rağmen 1980'li yıllardan sonra kadın gazetecilerin sayısal olarak artmalarına karşın etkinliklerinin artmamas1 günümüzde bir sorun olarak devam etmektedir. Nitekim medya yöneticilerinin büyük çoğunluğunun erkeklerden oluşması da bu durumu destekler niteliktedir.

Türkiye'de yayımlanan ulusal gazetelerin künyelerinin incelenmesi ve Ordu yerel basınında çalışan kadınların konumu ile yaşadıkları sorunların ortaya çıkarılmaya çalışıldığı bu çalışmada, yerel medya sektöründeki toplumsal cinsiyet ayrımının kadın çalışanlar üzerinde ne tür sorunlar oluşturduğu analiz edilmiştir. İncelenen literatür kapsamında medya işletmeleri yöneticilerinin önemli çoğunluğunun erkeklerden oluştuğu ve kadın çalışanların genelde orta düzeyde yani muhabirlik, yazı işleri gibi departmanlarda çalıştığı dolayısıyla da dikey ayrımcılığın olduğu sonucuna varılmıştır. Bununla birlikte yapılan araştırmalarda kadın gazetecilerin tıpkı yaygın medyada olduğu gibi örneğin spor ya da ekonomi sayfalarında yer almamaları da yatay ayrımcılığın bir göstergesidir.

21 ulusal gazetenin künyelerin incelendiği bu çalışmada ulusal basında çalışanların yüzde 14'ünün kadın yüzde 86'ının erkek olduğu sonucuna ulaşı1mıştır. 2014 yılında yapılan aynı araştırmada bu oranın kadın çalışanlarda yüzde 19 erkek çalışanlarda ise yüzde 81 'inin erkek olduğu görülmektedir. Güncellenen bu çalışma ile birlikte kadın çalışanların oranının azaldığı gözlemlense de 2014 yılında kapatılan 9 gazete dikkate alındığında aslında bu oranın çok fazla değişkenlik göstermediğini söylemek mümkündür. Araştırmaya göre sektörde imtiyaz sahibi ve yönetici konumunda olan erkeklerin cinsiyetçi bakış açısının sürdürülmesinde ve daha da yaygınlaştırılmasında egemen konumda olduğu sonucuna ulaşılabilir. $\mathrm{Bu}$ da kadın çalışanların üst kademelerde yönetici konumda çalışmasının önündeki büyük engeldir.

Aynı zamanda Ordu'daki yerel medyada çalışan kadınlarla yapılan görüşmelerde bazı kadınların uzun çalışma saatleri, ev ile iş arasında denge kurma gibi konularda sorun yaşadıkları görülmektedir. Bununla birlikte kadınlar çalıştıkları iş yerlerinde genel olarak medya patronları ve çalışma arkadaşları tarafından herhangi bir cinsiyetçi tutumla karşılaşmadıklarını ancak gerek işe alım sürecinde gerekse mesleklerini ifa ederken cinsiyetçi bakış açısıyla yaklaşıldığını ifade etmişlerdir.

Sonuç olarak kadınların istihdam sürecinde var olan toplumsal cinsiyet eşitsizliğinin ortadan kaldırılarak fırsat eşitliği sağlanması adına imzalanan sözleşmeler kapsamında yürütülen politikaların etkinliğinin artırılması gerekmektedir. Diğer tüm sektörlerde olduğu gibi medya sektöründe de çalışan kadınların sayılarının ve niteliklerinin artması için tüm alanlarda farkındalık oluşturulması, sadece kadın ve erkek arasında değil kadınlar arasında da yaşanan toplumsal cinsiyetçi bakış açısını en aza indirmek için kadınların daha çok örgütlenmesi, medya sahipleri tarafından kadın ve erkeklere aynı düzeyde istihdam firsatı verilmesi, dikey ve yatay ayrışmanın önüne geçmek için kadınlara girişim firsatı verilmesi, toplumsal cinsiyet eşitsizliğini ortadan kaldırmak için atılacak önemli adımlar arasında yer almaktadır. 


\section{KAYNAKÇA}

Alpsoy, İ. (2016). Erzurum Yerel ve Yaygın Basın Kuruluşlarında Çalışan Kadın Gazeteciler Üzerine Bir Alan Araştırması, Yayımlanmamış Yüksek Lisans Tezi, Atatürk Üniversitesi Sosyal Bilimler Enstitüsü, Erzurum.

Berktay, F. (2013). "Toplumsal Cinsiyet Çalışmaları", Eskişehir: Anadolu Üniversitesi Yayınları.

De Beauvoir, S. (1993). “Kadın İkinci Cins I- Genç Kızlık Çağı”" (çev. Bertan Onaran), İstanbul: Payel Yayınevi.

Giddens, A. (2012). “Sosyoloji”, İstanbul: Kırmızı Yayınlar1.

Kılıç A. (2013). Türk Basınında Kadın Gazetecilerin Yönetim ve Üretim Kademelerindeki Konumu. Yayımlanmamış Yüksek Lisans Tezi. Marmara Üniversitesi Sosyal Bilimler Enstitüsü, İstanbul.

Korkmaz, M. (2015). “Dünyada ve Türkiye'de Kadın ve Şiddet- Kadının Çalışma Hayatındaki Yeri ve Önemi”, Ankara: Nobel Akademi Yayıncılık.

Kuyucu, M. (2013). "Medyada Kadın Olmak: Medya İşletmelerinde Çalışan Kadınların Sorunları", Uluslararası Hakemli Beşeri ve Akademik Bilimler Dergisi, Cilt: 2 Sayı: 6, ss. 29-62.

Marshall, G. (1998). “Sosyoloji Sözlüğüu” (Çev. Osman Akınhay, Derya Kömürcü). Ankara: Bilim ve Sanat Yayınları.

Saygıllgil, F. (2016). “Toplumsal Cinsiyet
Tartışmaları", Dipnot Yayınları, Ankara.

Tahaoğlu, Çiçek (2014). “Medyanın Künyesi: Kaç Kadın Kaç Erkek?”

https://m.bianet.org/bianet/medya/154466-

medyanin-kunyesi-kac-kadin-kac-erkek (Erişim

Tarihi: 09.10.2018).

Türkiye Cumhuriyeti Başbakanlık Kadın Statüsü Genel Müdürlüğü, (2008). Politika Dokümanı "Kadın ve Medya”, Ankara.

Urhan, B. (2016). "Kadın Emeği ve Toplumsal Cinsiyet, Toplumsal Cinsiyet Tartışmaları" (yay. haz. Feryal Saygılıgil). Ankara: Dipnot Yayınları.

Yazıc1, Ç. (2016). "Felsefede Toplumsal Cinsiyet ve Feminizm, Toplumsal Cinsiyet Çalışmaları" (yay. haz. Feryal Saygılıgil). Ankara: Dipnot Yayınları 